\title{
Genetic evaluation of relationship between mutations in rpoB and resistance of Mycobacterium tuberculosis to rifampin Anna Zaczek ${ }^{1,2}$, Anna Brzostek ${ }^{1}$, Ewa Augustynowicz-Kopec ${ }^{3}$, Zofia Zwolska ${ }^{3}$ and Jaroslaw Dziadek*1
}

Address: ${ }^{1}$ Institute for Medical Biology, Polish Academy of Sciences, Lodz, Poland, 2Department of Genetics, University of Rzeszow, Rzeszow, Poland and ${ }^{3}$ Department of Microbiology, National Research Institute of Tuberculosis and Lung Diseases, Warsaw, Poland

Email: Anna Zaczek - ania.zaczek@yahoo.pl; Anna Brzostek - abrzostek@cbm.pan.pl; Ewa Augustynowicz-Kopec - e.kopec@igichp.edu.pl; Zofia Zwolska - z.zwolska@igichp.edu.pl; Jaroslaw Dziadek* - jdziadek@cbm.pan.pl

* Corresponding author

Published: 15 January 2009

BMC Microbiology 2009, 9:10 doi:10.1186/1471-2180-9-10
Received: 17 October 2008

Accepted: 15 January 2009

This article is available from: http://www.biomedcentral.com/I47/-2/80/9/10

(C) 2009 Zaczek et al; licensee BioMed Central Ltd.

This is an Open Access article distributed under the terms of the Creative Commons Attribution License (http://creativecommons.org/licenses/by/2.0), which permits unrestricted use, distribution, and reproduction in any medium, provided the original work is properly cited.

\begin{abstract}
Background: Rifampin is a first line antituberculosis drug active against bacilli in logarithmic and stationary phase, which interferes with RNA synthesis by binding to bacterial RNA polymerase. Tubercle bacilli achieve resistance to rifampin by accumulation of mutations in a short-8I bp region of the $r p o B$ gene. Among many mutations identified in the $r p o B$ gene, few were verified by molecular genetic methods as responsible for resistance to rifampin (RMP).
\end{abstract}

Results: In this study eight different mutations identified in an 81 bp section of a "hot spot" region of the rpoB gene of RMP resistant Mycobacterium tuberculosis clinical strains were evaluated in respect to drug resistance. It was found that: mutations in positions $526(\mathrm{H} / \mathrm{D}), 516(\mathrm{D} / \mathrm{V})$ and 53 I $(\mathrm{S} / \mathrm{L})$ result in high level resistance to rifampin; mutations in positions $516(\mathrm{D} / \mathrm{Y}), 515(\mathrm{M} / \mathrm{l}), 510(\mathrm{Q} /$ $\mathrm{H})$ or a double mutation in codons $5 / 2(\mathrm{~S} / \mathrm{I})$ and $5 / 6(\mathrm{D} / \mathrm{G})$ relate to low level of resistance. Gene rpoB carrying mutations in codon $5 / 3(\mathrm{Q} / \mathrm{L})$ introduced into an $M$. tuberculosis laboratory strain did not cause resistance to rifampin, however the same gene introduced into two different clinical strains did, with the level of resistance depending on the host strain.

Conclusion: Mutations in an $8 \mathrm{I} \mathrm{bp} \mathrm{"hot} \mathrm{spot"} \mathrm{region} \mathrm{of} \mathrm{the} \mathrm{rpoB} \mathrm{of} M$. tuberculosis lead to different levels of resistance to rifampin. Some mutations in this "hot spot" region of rpoB require a specific genetic background for the host strain to develop resistance to rifampin. Therefore, the identification of such mutations in a clinical $M$. tuberculosis strain is not enough to classify the given strain as resistant to rifampin.

\section{Background}

Tuberculosis (TB) is a devastating infectious disease causing high mortality and morbidity worldwide with 8 million new TB cases and 2-3 million deaths annually. The situation of TB is made even worse by the rising emergence of drug resistant strains of Mycobacterium tuberculo- sis. Multi-drug resistant TB (MDR-TB) is defined as resistant to at least isoniazid (INH) and rifampin (RMP), the two most active first-line drugs against TB. MDR-TB treatment takes up to 2 years with second line drugs, which are expensive and have side effects. In 2006 US Centers for Disease Control and Prevention (CDC) and 
the World Health Organization (WHO) drew attention to the emergence of $M$. tuberculosis with extensive drug resistance to second-line antituberculosis drugs (XDR). XDRTB is resistant to at least INH and RMP among the firstline drugs and to at least one of three injectable secondline anti-tuberculosis drugs used in TB treatment (capreomycin, kanamycin, amikacin) [1]. Thus, the treatment of such tuberculosis is becoming seriously limited, sometimes returning TB control to the pre-antibiotic era [1]. Tuberculosis chemotherapy started in 1944, when streptomycin (SM) was administered for the first time to a critically ill TB patient. Later, TB treatment was enriched with paraaminosalicylic acid (PAS-1949), INH (1952), pyrazinamide (PZA-1954), ethambutol (EMB-1962) and RMP (1963). It was identified that monotherapy generates drug-resistant mutants within a few months, endangering the success of antibiotic treatment. This problem was overcome by using combinations of drugs with as many as four drugs recommended nowadays by CDC and WHO [2].

The key antituberculosis drug commonly used in the treatment of tuberculosis is RMP. The loss of RMP as an effective drug leads to a need for a longer duration of therapy and often to a lower cure rate [3-6]. Drug resistance in $M$. tuberculosis is caused by mutations of various chromosomal genes, as identified for MDR occurrence due to the sequential accumulation of mutations in different genes that provide resistance to individual drugs. The individual molecular mechanisms of resistance have been identified for all first-line drugs and the majority of second-line drugs [7]. In M. tuberculosis, resistance to RMP results from mutations in the $\beta$-subunit of RNA polymerase, which is encoded by the $r p o \mathrm{~B}$ gene [8]. Approximately $95 \%$ of RMP-resistant strains carry mutations within an 81-bp region containing codons 507 through 533 of the $r p o B$ gene [8-10]. The single mechanism of resistance and narrow distribution of mutations make rpoB-81 bp region very attractive for molecular detection of resistance to RMP $[11,12]$. However, within several dozen different mutations detected in the $r p o B-81$ bp region of RMPresistant $M$. tuberculosis strains [for review see [13]], very few were tested by cloning and complementation assays. Mutated rpoB genes (S531L; H526Y; D516V) were introduced into the RMP sensitive M. tuberculosis $\mathrm{H}_{37} \mathrm{Rv}$ strain, resulting in acquired drug resistance of the host strain [14]. These authors observed that the level of acquired resistance was higher for mutants carrying mutations in codons 531 and 526 compared to mutation in codon 516. In this paper a genetic model was constructed allowing for a relatively simple verification of the relationship between the presence of a given mutation in $r p o B-81 \mathrm{bp}$ region and the RMP resistance of the host strain carrying such a mutation. Some $r p o B$ mutations revealed drug-resistance only in selected $M$. tuberculosis strains suggesting that genetic background of the host is important for the development of resistance to RMP.

\section{Methods}

\section{Bacterial strains and growth conditions}

The M. tuberculosis strains examined for this study were isolated from TB patients in Poland in 2000 during the second national survey of drug resistance $[12,15]$. Eight clinical strains identified as drug resistant, carrying different mutations in the $r p o B$ gene, and two susceptible strains identified as drug sensitive, which did not carry any mutation in $r p o B$, were selected. Moreover, a control laboratory strain $M$. tuberculosis $\mathrm{H}_{37} \mathrm{Ra}$, was included in this study. Primary isolation, differentiation, and drug susceptibility testing were performed with LowensteinJensen (LJ) medium and the BACTEC 460-TB system (Becton-Dickinson, Sparks, Md.), as reported earlier [15]. All mycobacterial strains used in this study were cultured in Middlebrook 7H9 broth supplemented with OADC (albumin-dextrose-sodium chloride) and with kanamycin $(25 \mu \mathrm{g} / \mathrm{ml})$, or hygromycin $(10 \mu \mathrm{g} / \mathrm{ml})$, when required. Mycobacterial transformants were selected on Middlebrook 7H10 agar plates enriched with OADC containing kanamycin (Km) or hygromycin (Hyg).

\section{Gene cloning strategies}

Standard molecular biology protocols were used for all cloning procedures [16]. All PCR products were obtained using thermostable ExTaq polymerase (Takara) and cloned initially into pGemT vector (Promega), sequenced, and then released by digestion with appropriate restriction enzymes before cloning into the final vectors. Some restriction enzymes recognition sites were incorporated into the sequence of primers. The primers and plasmids used in this work are listed in Table 1 and 2, respectively. To engineer various $r p o B$ genes of $M$. tuberculosis controlled by a natural promoter, a basal pRpoZero vector was constructed (Fig. 1). The vector contained the 5 ' end of $r p o B$ until a natural BstEII restriction enzyme recognition site (681 plus 950 bp of upstream region) which was connected to the 3 ' fragment of the gene starting with a natural BstEII restriction enzyme recognition site (1122 plus $218 \mathrm{bp}$ of downstream region). The resultant construct was used for cloning of the inner BstEII-BstEII fragment (1716 bp) of rpoB genes from various M. tuberculosis clinical strains resistant to RMP. The correct orientation of cloned BstEII fragments was verified by digestion with PvuII endonuclease. Next, the cloned genes controlled by their natural promoter, carrying given mutations or wild type sequence in the hot spot region were relocated into the pMV306 integration vector. The resultant constructs (pMRP1-9) were electrotransformed into RMP susceptible strains, and the integration of DNA was monitored by Km selection and verified by PCR. Alternatively, the investigated $r p o B$ genes were relocated without putative pro- 


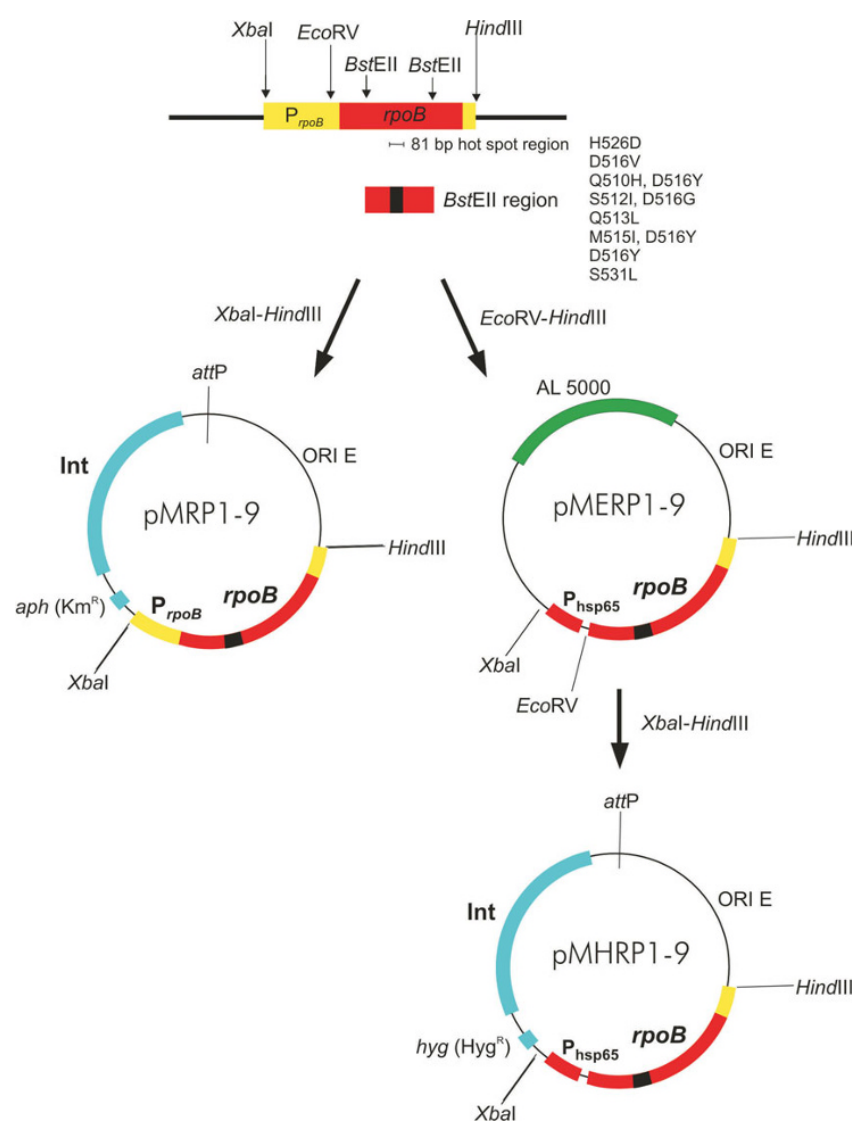

Figure I

Construction strategy of integration (pMRP I-9; pMHRP I-9) and self-replicating (pMERP I-9) plasmids carrying wild type and mutated $r p o B$ genes under control of own (pMRPI-9) and heat shock (pMHRPI9; pMERP I-9) promoter. Description in the text.

moter sequence into pMV306 $\mathrm{P}_{h s p}$ integration vector under control of strong promoter $\left(\mathrm{P}_{h s p 65}\right)$. The resultant constructs (pMHRP1-9) were electrotransformed into RMP susceptible strains, and the integration of DNA was monitored by Hyg selection and verified by PCR.

\section{Susceptibility testing}

Susceptibility testing was conducted using the proportion method on Youmans' liquid medium supplemented with $10 \%$ OADC with seven concentrations of RMP $(50,25$, $12.5,6.2,1.5,0.75,0.37 \mu \mathrm{g} / \mathrm{ml})$. The growth was determined after 21 days of incubation. The results were verified by Alamar Blue Assay [17-19] and by plating bacteria on Middlebrook 7H10 supplemented with OADC and various concentrations of RMP.

\section{Results}

The level of RMP resistance depends on the site and kind of substitution identified in the rpoB gene

The epidemiological studies carried out in many clinical laboratories worldwide have revealed several dozen mutations present in the rpoB gene of RMP resistant M. tuberculosis strains [12,14,20-23]. According to our knowledge, only three specific mutations of $r p o B$ have been verified so far by molecular cloning techniques [14]. The complementation of RMP sensitive $M$. tuberculosis strain with $r p o B$ gene carrying given mutation is not simply due to the gene length (3519 bp). One step amplification of gene together with its putative promoter based on M. tuberculosis genomic DNA as a template and its cloning is rather tough for investigators. To avoid this problem we have engineered pRpoZero vector carrying a 950 bp putative promoter region followed by $5^{\prime}(721 \mathrm{bp})$ and $3^{\prime}$ (1258 bp) $r p o B$ gene fragments of an RMP-sensitive $M$. tuberculosis $\mathrm{H}_{37}$ Ra strain (Fig. 1). The missing inner part of the $r p o B$ gene flanked with natural BstEII restriction sites contains an 81-bp mutable region. The BstEII fragment (1716 bp) of $r p o B$ gene can be easily amplified based on genomic DNA isolated from investigated M. tuberculosis RMP-resistant strains and cloned in frame to complete the $r p o B$ gene in the pRpoZero system.

In this study we have selected eight M. tuberculosis RMPresistant clinical strains carrying different mutations in $r p o B$ gene [12] (Table 3). The PCR generated BstEII inner fragments of the $r p o B$ gene were verified by sequencing and were cloned into the pRpoZero vector. The correct orientation of insert was confirmed by PvuII restriction analysis. Subsequently, the constructed genes, together with

Table I: Primer sequences used for PCR amplification

\begin{tabular}{|c|c|c|c|}
\hline Amplified region & Primer & Sequence & Product size (bp) \\
\hline \multirow[t]{2}{*}{ promoter region ( $950 \mathrm{bp})$ and 5 ' part of $r p o B$ gene ( $721 \mathrm{bp})$} & P-rpo-s & 5'-tctagacgagagcggcggtgcaatc & 1671 \\
\hline & P-rpo-r & 5 '-gctcgctggtccagcccagc & \\
\hline \multirow{2}{*}{ 3' part of rpoB gene (1258 bp) and downstream region ( 218 bp) } & 3'rpo-s & 5'-cgacaccaagctgggtgcgg & 1476 \\
\hline & 3'rpo-r & 5'-aagcttccagtcgcgagtcggcccg & \\
\hline \multirow[t]{2}{*}{ BstEll fragment of rpoB gene including $8 \mathrm{I}$-bp hot spot region } & bst-s & $5 '$-cgcgacaccgtcggcgtgcg & 1852 \\
\hline & bst-r & 5 -aagtgtcgcgcacctcgcgggc & \\
\hline \multirow[t]{2}{*}{ pMV306 (22I bp) and insert DNA cloned in MCS of this vector } & $M V-r$ & 5 '-aaggcccagtctttcgactgagc & $221+$ insert \\
\hline & MV-s & 5 -gtggataaccgtattaccgcc & DNA \\
\hline
\end{tabular}


Table 2: Plasmids used in this study

\begin{tabular}{|c|c|c|}
\hline Plasmid & Description & Source \\
\hline \multicolumn{3}{|c|}{ Cloning vectors } \\
\hline pGemTEasy & T/A cloning & Promega \\
\hline pMV306H & mycobacterial integrating vector, HygR & Med-Immune Inc. \\
\hline PMV306K & mycobacterial integrating vector, $\mathrm{Kan}^{\mathrm{R}}$ & Med-Immune Inc. \\
\hline pMV26I & mycobacterial Escherichia coli shuttle vector, carrying heat shock $\left(\mathrm{P}_{h s p 65}\right)$ promoter, $\mathrm{Km}^{\mathrm{R}}$ & Med-Immune Inc. \\
\hline \multicolumn{3}{|c|}{ RpoB expression vectors } \\
\hline PMRPI & $\begin{array}{l}\text { wild type } r p o B \text { of } M \text {. tuberculosis } \mathrm{H}_{37} \mathrm{Ra} \text { controlled by natural promoter } P_{r p o B} \text { cloned in integration vector } \\
\text { pMV } 306 \mathrm{~K}, \mathrm{Kan} R\end{array}$ & This study \\
\hline PMRP2-9 & $\begin{array}{l}\text { mutated } r p o B \text { of } M \text {. tuberculosis clinical strains controlled by natural promoter } P_{\text {rpoB }} \text { cloned in integration vector } \\
\text { pMV306K; 2-represents H526D; 3-D5I6V; 4-Q5I0H/D5I6Y; 5-S5I2I/D5I6G; 6-Q5I3L; 7-M5I5I/D5I6Y; 8- } \\
\text { D5I6Y; 9-S53IL, respectively, KanR }\end{array}$ & This study \\
\hline PMERPI & wild type $r p o B$ of $M$. tuberculosis $\mathrm{H}_{37} \mathrm{Ra}$ controlled by heat shock promoter $\mathrm{P}_{h s p 65}$ in pMV26I, $\operatorname{Kan}^{\mathrm{R}}$ & This study \\
\hline PMERP2-9 & $\begin{array}{l}\text { mutated rpoB of } M \text {. tuberculosis clinical strains controlled by heat shock promoter } \mathrm{P}_{\text {hsp65 }} \text { in pMV26I, 2-represents } \\
\text { H526D; 3-D5I6V; 4-Q510H/D516Y; 5-S5I2I/D516G; 6-Q5I3L; 7-M5I5I/D516Y; 8-D5I6Y; 9-S53IL, } \\
\text { respectively, KanR }\end{array}$ & This study \\
\hline PMHRPI & wild type $r p o B$ of $M$. tuberculosis $\mathrm{H}_{37} \mathrm{Ra}$ controlled by heat shock promoter $\mathrm{P}_{\text {hsp65 }}$ in pMV306, HygR & This study \\
\hline PMHRP2-9 & $\begin{array}{l}\text { mutated rpoB of } M \text {. tuberculosis clinical strains controlled by heat shock promoter } \mathrm{P}_{h p 65} \text { in pMV306, '2-represents } \\
\text { H526D; 3-D5I6V; 4-Q5I0H/D516Y; 5-S5I2I/D5I6G; 6-Q5 I3L; 7-M5I5I/D5I6Y; 8-D5I6Y; 9-S53IL, } \\
\text { respectively, HygR }\end{array}$ & This study \\
\hline
\end{tabular}

the putative promoter region, were relocated into the pMV306 integration vector using XbaI and HindIII restriction enzymes. The resultant constructs carrying wild type or mutated $r p o B$ genes under control of a natural promoter, were electroporated into an RMP-sensitive $M$. tuberculosis $\mathrm{H}_{37} \mathrm{Ra}$ host. The integration of plasmid DNA into the $a t t B$ site of chromosomal DNA was verified by PCR using MVs and MVr primers.

The wild type clinical strains and engineered M. tuberculosis $\mathrm{H}_{37} \mathrm{Ra}$ mutants were subjected to RMP-resistance analysis using the proportional method. Each strain was encoded by number and analyzed at least three times by standard procedure at the National Reference Center for Mycobacteria in Poland. The results obtained by the proportional method were verified using Alamar Blue Assay and by plating bacteria on Middebrook 7H10 supplemented with OADC and various concentrations of RMP (data not shown). The results obtained for clinical strains and engineered mutants are summarized in Table 3 and 4, respectively. Only three out of eight analyzed mutations (H526D; D516V; S531L) revealed the same level of RMPresistance in clinical strains and engineered $\mathrm{H}_{37} \mathrm{Ra}$ mutants. Introduction of other mutations identified in RMP-resistant $M$. tuberculosis clinical strains into the $\mathrm{H}_{37} \mathrm{Ra}$ host did not result in resistance to RMP or the level

Table 3: Rifampin resistance of clinical and control $M$. tuberculosis strains

\begin{tabular}{|c|c|c|}
\hline M. tuberculosis clinical strains & mutated amino acid of RpoB & MIC of rifampin ( $\mathrm{g} / \mathrm{ml})$ \\
\hline Mt.2 & H526D & 25 \\
\hline Mt.3 & D5 I6V & 25 \\
\hline Mt.4 & Q5I0H; D5I6Y & 25 \\
\hline Mt.5 & S5I2I; D5I6G & 12,5 \\
\hline Mt.6 & Q5I3L & 50 \\
\hline Mt.7 & M5I5I; D5I6Y & 25 \\
\hline Mt.8 & D5I6Y & 12,5 \\
\hline Mt.9 & S53IL & 25 \\
\hline KLI936 & - & 1,5 \\
\hline KL463 & - & 1,5 \\
\hline \multicolumn{3}{|l|}{ control strain } \\
\hline $\mathrm{H}_{37} \mathrm{Ra}$ & - & 1,5 \\
\hline
\end{tabular}


Table 4: Rifampin resistance of $M$. tuberculosis recombinant clones

\begin{tabular}{|c|c|c|c|c|}
\hline \multirow{3}{*}{$\begin{array}{l}\text { mutated amino acid of } \\
\qquad \text { RpoB }\end{array}$} & \multicolumn{4}{|c|}{$\begin{array}{c}\text { MIC of rifampin ( } \mathrm{g} / \mathrm{ml} \text { ) of } M . \text { tuberculosis recombinant clones carrying mutated } r p o B \text { gene controlled } \\
\text { by: }\end{array}$} \\
\hline & & PrpoB & & Phsp65 \\
\hline & $\mathbf{H}_{37} \mathbf{R a}$ & KLI936 & KL463 & H37Ra \\
\hline$H 526 D$ & 50 & 50 & 50 & 50 \\
\hline D516V & 25 & 25 & 25 & 25 \\
\hline Q5IOH; D5I6Y & 1,5 & 6,2 & 6,2 & 6,2 \\
\hline S5I2I; D5I6G & 6,2 & 6,2 & 6,2 & 6,2 \\
\hline Q5I3L & 6,2 & 12,5 & 50 & 6,2 \\
\hline M5I5I; D5I6Y & 6,2 & 6,2 & 6,2 & 6,2 \\
\hline D516Y & 3,1 & 6,2 & 3,1 & 6,2 \\
\hline S53IL & 50 & 50 & 50 & 50 \\
\hline
\end{tabular}

of MIC was very low in comparison with clinical strains. Mutation of codon 516 substituting D with $\mathrm{V}$ resulted in a high level of RMP resistance. This effect was not observed when D was substituted with $Y$ or $G$, even when an extra mutation was present in codon 510, 512 or 515 .

\section{Some rpoB mutations are able to cause RMP resistance} only in a particular $M$. tuberculosis host

The observed different levels of resistance of $M$. tuberculosis clinical strains and $\mathrm{H}_{37} \mathrm{Ra}$ strain carrying $r p o B$ genes mutated at the same positions lead to the conclusion that some mutations in the $r p o B$ gene can reveal drug-resistant phenotype only in a specific genetic background of the host. To verify this hypothesis integration vectors carrying mutated $r p o B$ genes under natural promoters were introduced by electroporation into two M. tuberculosis clinical strains (KL463; KL1936) sensitive to RMP. The selected transformants were verified by PCR amplification as described above. The resultant clinical strains carrying mutated $r p o B$ genes were subjected to RMP resistance analysis by the proportional method. The results obtained were compared to the RMP-resistance of clinical strains carrying the same mutations and to the $\mathrm{H}_{37} \mathrm{Ra}$ recombinants described above (Table 4). The mutated $r p o B$ genes generating high RMP-resistance level in M. tuberculosis $\mathrm{H}_{37} \mathrm{Ra}$ (H526D; D516V; S531L) were also responsible for high level of resistance of both clinical strains when introduced into their chromosomal DNA. On the other hand, mutation Q513L identified in an M. tuberculosis strain with resistance to a high level of RMP (MIC up to 50 $\mu \mathrm{g} / \mathrm{ml}$ ) which did not cause significant resistance of $M$. tuberculosis $\mathrm{H}_{37} \mathrm{Ra}$ (MIC up to $6.2 \mu \mathrm{g} / \mathrm{ml}$ ), was responsible for RMP-resistance of KL463 and KL1936 strains at the level depending on the host (up to 12.5 and $50 \mu \mathrm{g} / \mathrm{ml}$, respectively). The double mutation of $r p o B$ in positions $510(\mathrm{Q} / \mathrm{H})$ and $516(\mathrm{D} / \mathrm{Y})$ identified in a highly resistant M. tuberculosis strain (MIC $25 \mu \mathrm{g} / \mathrm{ml}$ ) which did not reveal resistance in $\mathrm{H}_{37} \mathrm{Ra}$ (MIC $1.5 \mu \mathrm{g} / \mathrm{ml}$ ) was responsible for low level of resistance of both clinical tubercle bacilli hosts (MIC $6.2 \mu \mathrm{g} / \mathrm{ml}$ ).

The overproduction of mutated RpoB does not cause high level of resistance to RMP

We could not exclude that the different resistance of $M$. tuberculosis hosts carrying identical mutations in $r p o B$ depends on different expression of RpoB controlled by unknown regulatory proteins. For example, the raised expression of target molecule (InhA) due to accumulations of mutations in promoter region is one of the known mechanisms of resistance to INH. As questions arose as to whether expression of mutated $r p o B$ genes under control of the heat shock promoter $\left(P_{h s p 60}\right)$ resulted in increased resistance of $M$. tuberculosis to RMP, the wild type $r p o B$ and its mutated copies were cloned under control of the heat shock promoter as described in Methods. Although we did not have antibodies to test the level of expression for RpoB, the expression system is known to be very efficient $[24,25]$. The self-replicating constructs (pMERP1-9, Fig. 1) appeared to be very unstable when introduced into M. tuberculosis host (data not shown). Therefore the vectors (pMHRP1-9), which are able to integrate into attB site of mycobacterial chromosomal DNA, carrying wild type and mutated $r p o B$ under $P_{h s p 60}$ promoter were constructed and electroporated into M. tuberculosis $\mathrm{H}_{37} \mathrm{Ra}$. The presence of the relevant DNA introduced into the attB site of chromosomal DNA was verified by PCR amplification. The resultant recombinant strains were subjected to RMP resistance analysis by the proportional method. The results of RMP-MIC analysis obtained for strains carrying mutated $r p o B$ genes under control of the strong $P_{h s p 60}$ promoter were similar to strains carrying the same $r p o B$ genes under control of their natural promoter (Table 4). These observations suggest that the RMP-resistance of M. tuberculosis strains carrying $r p o B$ mutated genes 
was not dependent on the rpoB expression level but resulted from the host genetic background that influence the drug-resistance phenotype.

\section{Discussion}

All bacteria achieve resistance to RMP by mutations in a defined region of the RNA polymerase subunit $\beta$. In $M$. tuberculosis, approximately $95 \%$ of RMP resistant clinical isolates carry a mutation in the rpoB gene [8]. On the other hand, many isolates from $M$. avium and $M$. intracellulare present a natural resistance to RMP as a result of an efficient permeability and exclusion barrier $[26,27]$. Mutations in $r p o B$ generally result in high level resistance to RMP. However, specific mutations in codons 511, 516, 518 and 522 can result in a lower resistance to RMP $[14,28,29]$. The role of some rpoB mutations (H526Y, S531L, D516V) in causing resistance was confirmed by genetic transformation experiments [14,30]. Several dozen other mutations identified in the rpoB gene of RMPresistant $M$. tuberculosis clinical isolates have never been confirmed by genetic cloning [12,31-35]. Nowadays, when many genetic techniques are well developed, the knowledge about mutations connected to RMP-resistance is becoming used in the rapid identification of drug resistance $[11,12,36,37]$. However, the utility of these techniques depends on the precise information about the role of any given mutation in RMP resistance.

In this study we have engineered a genetic system which is helpful in the verification of the relationship between the presence of a given mutation in $r p o B$ and RMP resistance. We have found that $r p o B$ gene carrying either D516V or S531L mutation causes resistance to RMP when introduced into the M. tuberculosis hosts what was in agreement with previous investigations [14]. On the other hand, when mutated $r p o B$ was introduced into drug sensitive $M$. tuberculosis laboratory or clinical strains, the other substitutions in position $516(\mathrm{D} / \mathrm{Y} ; \mathrm{D} / \mathrm{G})$, even when supported with Q510H, M515I or S512I identified in RMP-resistant M. tuberculosis clinical strains, did not result in a significant increase of RMP-resistance. Other authors previously reported the identification of D516Y substitutions of $r p o B$ in M. tuberculosis resistance to a high level of RMP [21,38], low level of RMP [14] and in strains sensitive to RMP [39]. Taken together, this suggests that D516Y/G substitutions in $r p o B$ are not sufficient to result in RMP-resistance of $M$. tuberculosis. The substitutions in codon $526(\mathrm{H} / \mathrm{Y}, \mathrm{D}, \mathrm{R}, \mathrm{L}$, $\mathrm{P})$ were usually identified in $\mathrm{M}$. tuberculosis clinical isolates highly resistant to $\operatorname{RMP}[14,23,38]$. In this paper we have provided direct evidence that mutation H526D in $r p o B$ is responsible for RMP-resistance when introduced into M. tuberculosis host. This result is similar to a previous finding verified by genetic transformation of $r p o B$ carrying mutation H526Y [14]. By contrast, the contribution of $r p o B$ carrying Q513L mutation to RMP-resistance was not that evident. The insertion of this gene into an M. tuberculosis $\mathrm{H}_{37} \mathrm{Ra}$ laboratory strain did not result in a significant level of RMP-resistance, however the insertion of the same gene was responsible for resistance to RMP of two $M$. tuberculosis clinical strains (MIC 12.5 and $50 \mu \mathrm{g} / \mathrm{ml}$ ) when used as hosts. As identified in various clinical studies, the level of RMP-resistance of $M$. tuberculosis isolates carrying the Q513L mutation varies from 2 to $200 \mu \mathrm{g} / \mathrm{ml}$ $[14,20,21,23,38]$. The collected results suggest that $r p o B$ carrying Q513L mutation is able to cause resistance to RMP only in selected tubercle bacilli. It is likely that this mutation can result in RMP-resistance in strains with low cell wall permeability since this exclusion barrier is responsible for natural resistance of some MAIC strains $[26,27]$. We also cannot exclude the possibility that other mechanisms support RMP-resistance of strains carrying Q513L mutation.

The drug resistance of $M$. tuberculosis can be also connected to the overproduction of a drug target due to accumulation of point mutations in a promoter region [4042]. To test whether overproduction of $r p o B$ carrying a given mutation result in higher MIC for RMP compared to a strain expressing the same gene under control of the natural promoter, $r p o B$ genes were cloned under control of the $P_{h s p}$ promoter and introduced into M. tuberculosis host. The $P_{h s p}$ promoter, commonly used in genetics studies of mycobacteria controlling the groEL gene (Rv0440) in M. tuberculosis, has already been reported as highly active in mycobacterial cells growing in vitro $[24,25]$. A recent microarray study showed that the expression level of groEL in $M$. tuberculosis cells growing in log phase is high, but not higher than $r p o B$ [43]. However, the arresting of $M$. tuberculosis growth results in 3.6-fold induction of groEL with a decrease of $r p o B$ expression in the same conditions [44]. We have not observed higher RMP resistance when mutated $r p o B$ genes were expressed under control of $P_{h s p}$ promoter in comparison to the natural promoter. It is possible that the natural level of RpoB is high enough to saturate RMP (if its concentration in cell is low). On the other hand, the extra expression of $r p o B$ cannot help in cells accumulating high RMP level. However, to elucidate this problem an alternative expression system and precise control of protein expression would be required.

The natural resistance to RMP in some M. avium and M. intracellulare strains is known to be as a result of an efficient cell wall permeability and exclusion barrier $[26,27]$, suggesting that these elements may be also important in M. tuberculosis. Changes in cell wall composition could affect permeability [45] decreasing the intracellular concentration of drug. 


\section{Conclusion}

Among several dozen amino acid substitutions identified in an $r p o B$ 81-bp region only a few are directly responsible for M. tuberculosis resistance to rifampin. Many others require a specific genetic background to develop resistance. Our findings lead to the conclusion that direct, molecular identification of rifampin resistant $M$. tuberculosis clinical isolates is possible only for strains carrying selected mutations in RpoB. The identification of other mutations suggests that investigated strains might be resistant to this drug.

\section{Authors' contributions}

AZ performed the majority of experiments. $A B$ helped in cloning. EAK and ZZ supervised susceptibility tests. JD conceived and supervised the study and wrote the manuscript. All authors have read and approved the final version of the manuscript.

\section{Acknowledgements}

We acknowledge financial support from grants R I 30203 and N40 I I48 3I/ 3268 awarded by the Polish Ministry of Science and Higher Education. We thank Dr. Richard Bowater for critical reading of this manuscript.

\section{References}

I. Raviglione M: XDR-TB: entering the post-antibiotic era? Int J Tuberc Lung Dis 2006, 10: I 185-87.

2. Ormerod LP: Directly observed therapy (DOT) for tuberculosis: why, when, how and if? Thorax 1999, 54 Suppl 2:S42-S45.

3. Mitchison DA, Nunn AJ: Influence of initial drug resistance on the response to short-course chemotherapy of pulmonary tuberculosis. Am Rev Respir Dis 1986, 133:423-430.

4. Espinal MA, Dye C, Raviglione M, Kochi A: Rational 'DOTS plus' for the control of MDR-TB. Int J Tuberc Lung Dis 1999, 3:56 I-3.

5. World Health Organization: Anti-tuberculosis drug resistance in the world. The WHO/IUATLD Global Project on AntiTuberculosis Drug Resistance Surveillance (WHO/TB/ 97.229). WHO Geneva Switzerland; 1997.

6. World Health Organization: Anti-tuberculosis drug resistance in the world. Third Global Report. The WHO/IUATLD Global Project on Anti-Tuberculosis Drug Resistance Surveillance (WHO/CDC/TB/2004). WHO Geneva Switzerland; 2004.

7. Zhang Y, Vilcheze C, Jacobs WR Jr: Mechanisms of drug resistance in Mycobacterium tuberculosis. In Tuberculosis and the Tubercle Bacillus ASM Press Washington DC; 2005: I I5-140.

8. Telenti A, Imboden P, Marchesi F, Lowrie D, Cole S, Colston MJ, Matter L, Schopfer K, Bodmer T: Detection of rifampicin-resistance mutations in Mycobacterium tuberculosis. Lancet 1993, 341:647-50.

9. Musser JM: Antimicrobial agent resistance in mycobacteria: molecular genetic insights. Clin Microbiol Rev 1995, 8:496-5I4.

10. Williams DL, Waguespack C, Eisenach K, Crawford JT, Portaels F, Salfinger M, Nolan CM, Abe C, Sticht-Groh V, Gillis TP: Characterization of rifampin-resistance in pathogenic mycobacteria. Antimicrob Agents Chemother 1994, 38:2380-6.

II. Caoili JC, Mayorova A, Sikes D, Hickman L, Plikaytis BB, Shinnick TM: Evaluation of the TB-Biochip oligonucleotide microarray system for rapid detection of rifampin resistance in Mycobacterium tuberculosis. J Clin Microbiol 2006, 44:2378-8I.

12. Sajduda A, Brzostek A, Pop\&\#x0 I 42;awska M, Augustynowicz-Kopec E, Zwolska Z, Niemann S, Dziadek J, Hillemann D: Molecular characterisation of rifampin-resistant Mycobacterium tuberculosis starins isolated in Poland. J Clin Microbiol 2004, 42:2425-3I.

13. Zhang Y, Telenti A: Genetics of drug resistance in Mycobacterium tuberculosis. In Molecular Genetics of Mycobacteria ASM Press Washington DC; 2000:235-253.

14. Williams DL, Spring L, Collins L, Miller LP, Heifets LB, Gangadharam PR, Gillis TP: Contribution of rpoB mutations to development of rifamycin cross-resistance in Mycobacterium tuberculosis. Antimicrob Agents Chemother 1998, 42: I853-57.

15. Augustynowicz-Kopec E, Zwolska Z, Jaworski A, Kostrzewa E, Klatt M: Drug resistant tuberculosis in Poland in 2000: second national survey and comparison with the 1997 survey. Int J Tuberc Lung Dis 2003, 7:1-7.

16. Sambrook J, Russel DW: Molecular Cloning: A Laboratory Manual. Cold Spring Harbor Laboratory Press; 200I.

17. Collins LA, Franzblau SG: Microplate Alamar Blue Assay versus BACTEC 460 system for hight-throughput screening of compounds against Mycobacterium tuberculosis and Mycobacterium avium. Antimicrob Agents Chemother 1997, 41:1004-09.

18. Franzblau SG, Witzig RS, McLaughlin JC, Torres P, Madico G, Hernandez A, Degnan MT, Cook MB, Quenzer VK, Ferguson RM, Gilman RH: Rapid, low-technology MIC determination with clinical Mycobacterium tuberculosis isolates by using the Microplate Alamar Blue Assay. J Clin Microbiol 1998, 36:362-6.

19. Reis RS, Neves I Jr, Lourenco SLS, Fonseca LS, Lourenco MCS: Comparison of Flow Cytometric and Alamar Blue Test with the Proportional Method for testing susceptibility of Mycobacterium tuberculosis to rifampin and isoniazid. J Clin Microbiol 2004, 42:2247-48.

20. Taniguchi H, Aramaki H, Nikaido Y, Mizuguchi $Y$, Nakamura M, Koga $T$, Yoshida S: Rifampicin resistance and mutation of the rpoB gene in Mycobacterium tuberculosis. FEMS Microbiol Letters 1996, 144:103-08.

21. Yang B, Koga H, Ohno H, Ogawa K, Fukuda M, Hirakata Y, Maesaki $S$, Tomono K, Tashiro T, Kohno S: Detection between antimicrobacterial activities of rifampicin, rifabutin and KRM- 1648 and rpoB mutations of Mycobacterium tuberculosis. I Antimicrob Chemother 1998, 42:621-28.

22. Chan RCY, Hui M, Chan EWC, Au TK, Chin ML, Yip CK, AuYeang CKW, Yeung CYL, Kam KM, Yip PCW, Cheng AFB: Genetic and phenotypic characterization of drug-resistant Mycobacterium tuberculosis isolates in Hong Kong. J Antimicrob Chemother 2007, 59:866-73.

23. Huitric $E$, Werngren J, Jureen $P$, Hoffner $S$ : Resistance levels and rpoB gene mutations among in vitro-selected rifampinresistant Mycobacterium tuberculosis mutants. Antimicrob Agents Chemother 2006, 50:2860-62.

24. Dziadek J, Madiraju MVVS, Rutherford SA, Atkinson MAL, Rajagopalan M: Physiological consequences associated with overproduction of Mycobacterium tuberculosis FtsZ in mycobacterial hosts. Microbiology 2002, 148:96I-7I.

25. Brzostek A, Sliwinski T, Rumijowska-Galewicz A, Korycka-Machala M, Dziadek J: Identification and targeted disruption of the gene encoding the main 3-ketosteroid dehydrogenase in Mycobacterium smegmatis. Microbiology 2005, I 5 I:2393-2402.

26. Hui J, Gordon N, Kajioka R: Permeability barrier to rifampin in mycobacteria. Antimicrob Agents Chemother 1977, I I:773-79.

27. Guerrero C, Stockman L, Marchesi F, Bodmer T, Roberts GD, Telenti $A$ : Evaluation of the rpoB gene in rifampicin-susceptible and -resistant Mycobacterium avium and Mycobacterium intracellulare. J Antimicrob Chemother 1994, 33:66I-3.

28. Bodmer T, Zurcher G, Imboden P, Telenti A: Mutation position and type of substitution in the beta-subunit of the RNA polymerase influence in vitro activity of rifampin-resistant Mycobacterium tuberculosis. I Antimicrob Chemother 1995, 35:345-48.

29. Moghazeh SL, Pan X, Arain T, Stover CK, Musser JM, Kreiswirth BN: Comparative antimycobacterial activities of rifampin, rifapentine, and KRM- 1648 against a collection of rifampin-resistant Mycobacterium tuberculosis isolates with known rpoB mutations. Antimicrob Agents Chemother 1996, 40:2655-57.

30. Miller LP, Crafword JT, Shinnick TM: The rpoB gene of Mycobacterium tuberculosis. Antimicrob Agents Chemother 1994, 38:805-II.

31. Hillemann D, Kubica T, Rusch-Gerdes S, Niemann S: Disequilibrium in distribution of resistance mutations among Mycobacterium tuberculosis Beijing and Non-Beijing strains isolated from patients in Germany. Antimicrob Agents Chemother 2005, 49:|229-3|

32. Huang $\mathrm{H}$, Jin $\mathrm{Q}$, Chen $\mathrm{X}$, Zhuang $\mathrm{Y}$ : Characterization of rpoB mutations in rifampicin-resistant Mycobacterium tuberculosis isolated in China. Tubecrulosis 2000, 82:79-83.

33. Ozkutuk N, Gazi H, Surucuoglu S, Gunduz A, Ozbakkaloglu B: Characterization of rpoB mutations by Line Probe Assays in 
rifampicin-resistant Mycobacterium tuberculosis clinical isolates from the Aegean region in Turkey. Jpn J Infect Dis 2007, 60:211-13.

34. Bostanabad S, Bahrmand A, Titov LP, Taghikhani M: Identification of mutations in the rpoB encoding the RNA polymerase beta subunit in rifampicine-resistant Mycobacterium tuberculosis strains from Iran. Tuberk Toraks 2007, 55:370-77.

35. Brossier F, Veziris N, Truffot-Pernot C, Jarlier V, Sougakoff W: Performance of the genotype MTBDR line probe assay for detection of resistance to rifampin and isoniazid in strains of Mycobacterium tuberculosis with low- and high-level resistance. I Clin Microbiol 2006, 44:3659-3664.

36. Gryadunov D, Mikhailovich V, Lapa S, Roudinskii N, Donnikov M, Pan'kov S, Markova O, Kuz'min A, Chernousova L, Skotnikova O, Moroz A, Zasedatelev A, Mirzabekov A: Evaluation of hybridisation on oligonucleotide microarrays for analysis of drugresistant Mycobacterium tuberculosis. Clin Microbiol Infect 2005, I I:53I-9.

37. Mikhailovich V, Lapa S, Gryadunov D, Sobolev A, Strizhkov B, Chernyh N, Skotnikova O, Irtuganova O, Moroz A, Litvinov V, Vladimirskii M, Perelman M, Chernousova L, Erokhin V, Zasedatelev A, Mirzabekov A: Identification of rifampin-resistant Mycobacterium tuberculosis strains by hybridization, PCR, and ligase detection reaction on oligonucleotide microchips. J Clin Microbiol 200I, 39:253I-40.

38. Hwang H, Chang C, Chang L, Chang S, Chang Y, Chen Y: Characterisation of rifampicin-resistant Mycobacterium tuberculosis in Taiwan. J Clin Microbiol 2003, 52:239-45.

39. Somoskovi A, Dormandy J, Mitsani D, Rivenburg J, Salfinger M: Use of smear-positive samples to assess the PCR-based genotype MTBDR assay for rapid, direct detection of the Mycobacterium tuberculosis complex as well as its resistance to isoniazid and rifampin. J Clin Microbiol 2006, 44:4459-63.

40. Baneriee A, Dubnau E, Quemard A, Balasubramanian V, Um KS, Wilson $T$, Cillins $D$, de Lisle $G$, Jacobs WR Jr: inhA, a gene encoding a target for isoniazid and ethionamide in Mycobacterium tuberculosis. Science 1994, 263:227-30.

4I. Musser JM, Kapur V, Williams DL, Kreiswirth BN, van Soolingen D, van Embden JD: Characterization of the catalase-peroxidase gene (katG) and inhA locus in isoniazid-resistant and -susceptible strains of Mycobacterium tuberculosis by automated DNA sequencing: restricted array of mutations associated with drug resistance. J Infect Dis 1996, 173:196-202.

42. Basso LA, Zheng R, Musser JM, Jacobs WR Jr, Blanchard JS: Mechanisms of isoniazid resistance in Mycobacterium tuberculosis : enzymatic characterization of enoyl reductase mutants identified in isoniazid-resistant clinical isolates. I Infect Dis 1998, I 78:769-75.

43. Fu LM, Fu-Liu CS: The gene expression data of Mycobacterium tuberculosis based on Affymetrix gene chips provide insight into regulatory and hypothetical genes. BMC Microbiol 2007 , 1 4:7-37.

44. Karakousis PC, Yoshimatsu T, Lamichhane G, Woolwine SC, Nuermberger EL, Grosset J, Bishai WR: Dormancy phenotype displayed by extracellular Mycobacterium tuberculosis within artificial granulomas in mice. J Exp Med 2004, 200:647-57.

45. Korycka-Macha\&\#x0I42;a M, Rumijowska-Galewicz A, Dziadek J: The effect of ethambutol on mycobacterial cell wall permeability to hydrophobic compounds. Pol J Microbiol 2005, 54:5-I I.

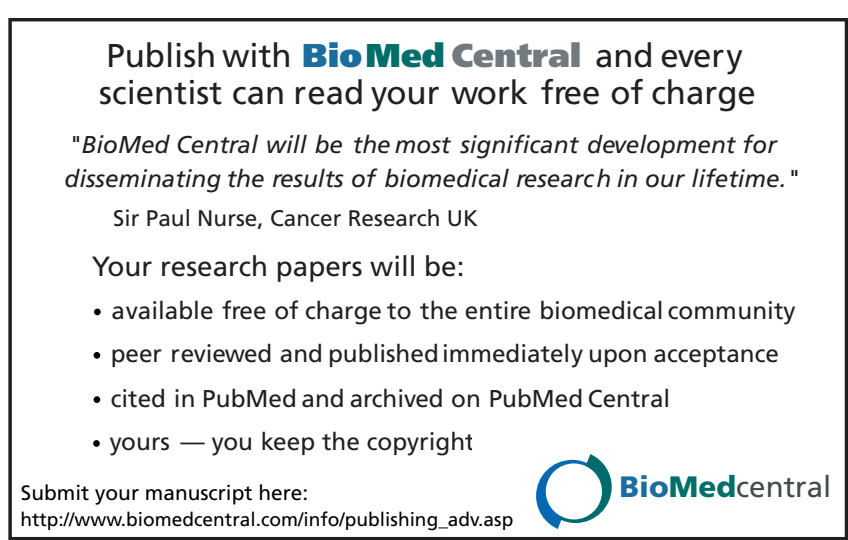

